\title{
Urban imaginaries: funding mega infrastructure projects in Lagos, Nigeria
}

\author{
Onyanta Adama $\mathbb{D}$
}

Published online: 31 January 2017

(C) The Author(s) 2017. This article is published with open access at Springerlink.com

\begin{abstract}
In today's globalized world, mega infrastructure projects have emerged as one of the most popular strategies for attracting private capital and repositioning cities on the competitive landscape. The Lagos Megacity Project (LMCP) was launched to address a longstanding infrastructure crisis and to reinvent Lagos as a modern megacity. Using the LMCP as a case study, the paper examined the challenges facing the funding of mega infrastructure projects. Special attention is given to how capital is mobilized, the kinds of alliances or networks found and what gets prioritized. The paper observed that the alliance formed between the federal, Lagos and Ogun state governments to mobilize public funds quickly unraveled largely due to disputes traceable to the apportioning of fiscal and political responsibilities and the distribution of functions between the different tiers of government. Under the LMCP, disputes emerged between the federal government and the Lagos State Government (LSG) over who was responsible for what. A history of opposition politics and a highly politicized resource allocation system further made cooperation between the two particularly difficult. Furthermore, the LMCP signalled a renewed drive by the LSG to attract private investments through publicprivate partnership. The paper noted a host of
\end{abstract}

O. Adama $(\bowtie)$

Stockholm University, Stockholm, Sweden e-mail: onyanta.adama@humangeo.su.se problems but crucially there is a preference for elite projects, a practice that is reinforcing socio-spatial exclusion and confirms the persistent inequalities that accompany neoliberal and modernist projects. At the broadest level, the paper points to how modernist projects are fractured or undermined by specific ideologies and practices.

Keywords Urban imaginaries · Modernity · Neoliberalism · Governmentality · Mega infrastructure $\cdot$ Lagos $\cdot$ Nigeria

\section{Introduction}

The drive by governments to reposition cities on the competitive landscape in response to global economic forces continues to generate interest among urban scholars. In today's globalized world, places compete with each other for their share of businesses, investments and capital (Anhold 2006 cited in Cleave and Arku 2015). Infrastructure development has emerged as a popular strategy for attracting private capital. In this context, large-scale urban development or mega projects have been described as some of "the most visible and ubiquitous urban revitalization strategies" initiated by city elites in search of economic growth and market competitiveness (Swyngedouw et al. 2002, p. 551). It is also worth noting that contemporary urban infrastructure is also a prerequisite to modern civilization and embodiment of Western 
Enlightenment ideas (Graham 2011). The provision of efficient infrastructure services is therefore seen as not only crucial to local economic growth but is intimately linked to the dream that the modern city promises its inhabitants (Ali and Rieker 2008). Mega projects have been widespread in Europe and the US in the last two decades where many cities have responded to the pressures of globalization by embarking on big, mixed-used development to attract multinational businesses (Fainstein 2008). Mega projects are increasingly becoming popular in African cities where current imaginaries reflect internationally circulating ideals that prioritize economic growth (Freund 2010) and the provision of infrastructure is intimately caught up with the sense of shaping modern society and realizing the future (Larkin 2013). There is little doubt that many of the mega cities in the global South face an increasing crisis in the provision of basic infrastructure (Gandy 2006). Infrastructures are inadequate and failing across the globe but the problem is more acute in cities in the South and especially in Africa which has witnessed decades of underinvestment due to illconceived privatization, increasing debt burden and administrative inefficiencies among others (Pieterse and Hyman 2014).

There is a pressing need to install new infrastructure in cities in the South in addition to maintaining old ones but finance is a major problem (Pieterse and Hyman 2014; Pessoa 2008; Kirkpatrick and Parker 2004). As observed, cities in developing countries require far more financing for infrastructure than can be provided by domestic public institutions (Pessoa 2008). Like their counterparts across the globe, city governments in Africa are seeking to bridge the deficit through private capital (Freund 2010). However, amidst the growing demand and policy interventions, infrastructure development is complex and highly politicized. It is a site of capitalist production and expansion and is constitutive of social relations of inequality (Larkin 2013; McFarlane and Rutherford 2008). There are technical, administrative, organizational, political, social and financial issues to consider. The paper pays particular to the financial but discussed in the broader context of historical, political and social processes. Furthermore, African cities are open to external influences but they also exhibit "cultural vitality, economic innovation, social mobility, political ambition and creative policy-making" (Robinson 2006a, p. 251). Thus infrastructure development raise wider questions concerning the nature of modernity and urban governance (Gandy 2006). Specifically, there is an interest in how modernity is shaped by place specific cultural practices and ideologies and how experiences of modernity are contested.

The city of Lagos, Nigeria needs little introduction among scholars of African urban studies. Lagos has become pivotal to recent debates among those who want to chart a new path for theorizing African cities (Fourchard 2011; Godlewski 2010; Watson 2009; Gandy 2005). They argue against the tendency to represent African cities as sites of decay characterized by lack of infrastructure and services and call for a shift in focus to an understanding of the complex processes taking place and how urban Africa is continuously reinventing itself in unpredictable ways. From a small farming and fishing village in the fifteenth century, Lagos is now one of the fastest growing cities in the world with an estimated population of over 15 million (Filani 2012). The huge growth in population has occurred alongside economic decline (Ilesanmi 2010). Lagos has faced numerous challenges including massive flooding, congested traffic, epileptic water and electricity supplies and inadequate housing (George 2009; Abiodun 1997). Colonial policy and planning had a huge effect on the form and functioning of the city (Home 2013). Located on the Atlantic coast, Lagos largely served colonial interests as a port facilitating the transportation of raw materials to Europe. There was a lack of investments in the built environment and a failure to construct integrated networks, a practice that was carried over to the postcolonial period (Gandy 2006). Furthermore, the administration of Lagos under different territorial schemes during the colonial period left a legacy of a complex system and the resultant fragmented political authority contributed to a lack of coordination in service delivery (Abiodun 1997). The attempts by successive governments to address the problems and the failures are well documented (Fourchard 2011; George 2009; Gandy 2006; Abiodun 1997). Several renewal efforts and planning interventions have occurred over the years including the Central Lagos Planning Scheme in the late 50s, a draft master plan (1965-1985) and a master plan (1980-2000) which produced an urban growth strategy (George 2009). 
The latest attempt to address the plethora of problems facing the government and people of Lagos is the Lagos Megacity Project (LMCP). The term 'megacity' has come to mean different things in the North and South. Mega cities in the North are often referred to as global cities but in the South, megacity has come to mean "chaotic, congested, overcrowded, polluted cities, with too many people living and working informally" (Sheppard 2014, p. 145). As used by the Lagos State Ministry of Physical Planning, the term megacity is based on the UN definition of a megacity as a metropolitan area with a population of over 10 million. The immediate motivation for the LMCP was the realization by the government that while Lagos had become a megacity, it lacked the infrastructure and services commensurate with that status. Thus a major aim of the LMCP is to address the infrastructure deficit. In addition and in a reflection of current modernist city visioning processes, the government also hoped to turn Lagos into a modern financial centre reminiscent of Manhattan in New York (Cossou 2010). As a megacity and a city of high political and economic significance in Nigeria, Lagos provides a setting for a network of global, national, regional and local actors. Funding was considered crucial to the success of the LMCP right from the onset and two alliances subsequently emerged from the pool of actors. The first involved the national or federal government and Lagos and Ogun State governments. The second brought global, national and local private firms and the Lagos State Government (LSG) into partnership arrangements under the public-private partnership (PPP) framework. The aim of this paper is to examine the challenges facing the funding of mega infrastructure projects in Lagos as seen through the LMCP and the workings of the two alliances. Particular attention is given to how capital is mobilized, how resources are allocated and the kinds of local and foreign institutions and entrepreneurial networks found and what gets prioritized.

\section{Urban imaginaries: modernity, neoliberalism, governmentality and the tensions}

The term 'urban imaginaries' has come to symbolize the ideology, logic or mentalities behind a wide range of issues related to the city, from architecture to social relations and urban policies. Of particular note is the idea of cities that planners and inhabitants produce and the contested visions that arise. Urban imaginaries entail a reimagining of the urban form and functions and a reordering of space (Ong 2011; Robinson 2006b). The desire to change or upgrade infrastructure fits into this vision (Ong 2011) and put mega infrastructure projects high on the agenda. In a reference to mega projects, Swyngedouw et al. (2002) observe that the imaginaries encompass repositioning the city on the competitive landscape and reimagining and recreating urban space not only in the eyes of city planners but also for the investor or developer. Evidently, urban imaginaries are embedded with ideologies, narratives, imaginations and visions that are deeply rooted in modernity (Amin 2006). Accounts of modernity describe the modern era as new, qualitatively different from, if not better than previous periods (Robinson 2006b). Often traced to late nineteenth- and twentieth-century Europe, modernity is inherently biased as reflected in the dichotomous distinctions between town/country (Lefebvre 1996), modern/tradition (Robinson 2006b) and order/ disorder (Mitchell 2003). Following from this, the terms 'modern' and 'modernity' have become central to the discourse on Eurocentrism. A major source of contention is the tendency to belittle experiences outside Europe. Modernity is often taken to be synonymous with the West and cities and societies outside the West represented as not so modern, traditional or primitive (Robinson 2006b). To the contrary, Robinson argues that Western modernity is only one moment in the "diverse circulations and productions of new things and new ways of being that are assembled in distinctive ways to produce different kinds of places and ways of understanding them" ( $\mathrm{p}$. 20). For example, Ong (2011, p. 14) observe how some Asian cities have become models of "urban futurity that does not find its ultimate reference in the West".

Closely associated with modernity is the discourse on how urban policies travel the globe, through which networks, and how they are politically negotiated and adapted (see Ward 2011). The debate is captured in references to 'mobile urbanism' and policy mobilities (McCann and Ward 2011), and 'worlding cities' (Ong 2011) among others. Policy mobilities is a deeply geographical enterprise and requires careful thought to the multiple and overlapping spaces of policy making (Cochrane and Ward 2012). This makes it particularly relevant to this paper since mega projects operate in 
and over a variety of scales (Swyngedouw et al. 2002). Understanding the complex processes associated with policy mobilities require attention to scale and context and suggests a careful examination of how local actors "draw in ideas, initiatives, and imaginaries from elsewhere, seeking to translate them from one context to another (Cochrane and Ward 2012, p. 9). For the purposes of this paper, scale is particularly relevant and will be discussed in more detail later. The term 'assemblages' is also used to highlight the diversity and complexity that accompany policy mobilities. Borrowing from Deleuze and Guattari's work, McCann and Ward (2011, p. Xv) see cities as assemblages "a rubric under which to frame the travels and transfers, political struggles, relational connections, and territorial fixities/mobilities brought together to constitute urbanism”. McCann and Ward add that urban assemblages shape and reconstitute wider flows; involve politics and practices; and embody tensions that make it possible to overcome analytical dichotomies such as fixity/mobility and global/local. Along these lines, Allen and Cochrane (2007 cited in McCann and Ward 2011) see a city as an assemblage of central, regional and local actors engaged in a complex set of political mobilizations. A similar approach is adopted in this paper in the conception of Lagos as a site of struggle and conflict between the different tiers of governments.

The attempt to locate modernity outside the West and a recognition of policy mobilities as an important phenomenon paves the way for understanding the tensions that accompany modernist projects in different places and why such projects may fail to realize their objectives. Gandy (2006) adopts an approach that takes into account modernism and the historical emergence of specific ideologies and techniques of governmental activity dating back to the colonial era to examine the infrastructure crisis in Lagos. Gandy reports that colonial administrators incorporated the existing traditional power structures into the formal apparatus of government resulting in a highly unstable legacy of authoritarian and undemocratic control over the African majority. Furthermore, investments in urban infrastructure were disproportionately concentrated in the European enclaves. In the end, cities like Lagos were characterized by what Gandy refers to as 'incomplete modernity', justified through the use of cultural distinctions between modernity and tradition, but resulting in the partial completion of services such as water and sanitation. Similarly, Shatkin (2011) observes that the transformation expected to accompany mega projects in many Asian cities is far from complete and in many cases have foundered due to a range of political, legal and cultural obstacles. With the exception of China, even the most successful mega projects have not fulfilled the grandiose ambitions of the developers. Some projects are behind schedule, others have failed financially and some are embroiled in legal controversies or face popular resistance.

Central to the debates on modernity and policy mobilities is neoliberalism (McCann and Ward 2011). Neoliberalism facilitates a freer-flow of capital and resources between competing places (Cleave and Arku 2015). In policy circles, neoliberalism takes the form of entrepreneurial governance and PPP. Entrepreneurial governance is a vital part of the globally circulating vision of successful urbanism and has become popular in the context of urban politics and the diverse set of practices aimed at attracting capital (Crossa 2009). Entrepreneurial governance advocates the reorientation of urban governance away from dominant state control to a model designed to encourage local growth and economic development (Hall and Hubbard 1996). PPP has become a veritable tool in the actualization of entrepreneurial governance. PPP is characterized by processes of downsizing, outsourcing, privatization as well as the restructuring of the state and the reordering of linkages among state agencies at all levels (Cleave and Arku 2015). Crucially, governments see PPP as a way of bringing in funding, technical expertise, innovation and management know-how from the private sector to address public policy problems (Forrer et al. 2010). However, entrepreneurial governance and PPP have attracted some criticism. A major thrust of entrepreneurial governance is a shift from the old to the new but some question if there has been any change. According to Hall and Hubbard (1996, p. 153), while there is a new vocabulary of cities as 'growth machines', of city advertising as 'place making' and of redevelopment as 'revitalization', it is not clear as to how fundamental the shift to entrepreneurism has been. This argument is particularly resonant in cities in the global South where there is a huge deficit in infrastructure funding and governments remain the main source of financing accounting for $70 \%$ with the private sector at $22 \%$ and official development assistance $8 \%$ (Pessoa 2008). Furthermore, there is little consensus as to how effective the 
new modes of governance are at addressing the fiscal and social problems associated with the modern urban crisis and the growing social polarizations in many cities (Hall and Hubbard 1996). For example, mega projects are risky for public and private participants (Fainstein 2008) and are therefore often built on a "for-profit basis" (Shatkin 2011, p. 77). There is evidence that links neoliberalism and entrepreneurism to the construction of new socio-economic environments (Brown et al. 2010; Lindell 2010; Swyngedouw et al. 2002). It is a common practice to exclude those who cannot pay for services. In a study on modernism and neoliberalism in São Paulo, Brazil, Caldeira (2008) reports that the public is being attacked, privatization rules and inequality is a value. Furthermore and contrary to expectations, changes associated with neoliberalism and competitive markets have made some municipalities vulnerable to fiscal decline and economic dislocation (Cleave and Arku 2015).

From the above, it is evident that neoliberalism is accompanied by certain logic, ideologies and practices. This necessitates a reference to the concept of governmentality. Coined by Michel Foucault, governmentality is a popular concept for addressing power relations in contemporary societies. It refers to a generally held view that is communicated by way of techniques of power that guide the behaviour of citizen-subjects (Dean 2010). According to Dean, the neoliberal and liberal rationality of government has four features; the economy, security, law and society. In the case of the economy, Dean cites three events in the emergence of the notion of the economy as a specific level of reality composed of distinct economic processes rather than a sphere of positive action on the part of the sovereign. The first is the economy as a 'quasi-nature' and "presupposes the existence of an order that is the source of wealth, that cannot be modified or tampered with, and drives appropriate state policy" (p. 134). The prioritization of entrepreneurial governance and PPP can be seen in this context. The second feature involves the restructuring of institutions of the state and society in a way that is consistent with the protocols of political economy while the third establishes "liberalism as a form of government through rather than of the economy (p. 134, emphasis original). The restructuring of the state and the way the government governs the society are given special attention in this paper.
Governmentality entails the notion of government as the 'conduct of conduct' and includes a rational set of ways of shaping conduct and securing rule through a variety of agencies and authorities (Watts 2004). To 'conduct' means to lead or guide and 'rational' refers "to the attempt to bring any form of rationality to the calculation about how to govern" (Dean 2010, p. 14, emphasis original). Rationality is any form of thinking which is relatively clear, systematic and explicit about how things are and how they ought to be. Governmentality encompasses discourses and practices related to the governance of a population and of the self. Both require 'governance at a distance', which explains how everyday activity is rationalized in terms of techniques of power by which the conduct of citizens is conducted. A major tenet is that a population has its own characteristic and is to be understood by means of specific knowledges and governed through techniques in line with the emergent understandings (Rose et al. 2006). Furthermore, governing requires the 'art of government' which suggests that "governing is an activity that requires craft, imagination, shrewd fashioning, the use of tacit skills and practical know-how..." (Dean 2010, p. 28). The examination of practices is also important in governmentality studies. As Ettlinger (2011) points out, the formulation of a research problem begins with an event, observations of particular practices that prompts contextualization and problematization. Practices possess their unique regularities, logic and strategy and 'a regime of practices' is a reference to "organized practices through which we are governed and through which we govern ourselves" (Dean 2010, p. 28).

The concepts and methodological approaches adopted in governmentality studies have spread widely because they resonated and coexisted with intellectual trends in some fields or disciplines (Rose et al. 2006). Foucault's view of the discipline of geography may have been narrow but governmentality is geographic at its core and provides insights into geographic issues (Ettlinger 2011). Ettlinger sees a link between governmentality and relational thinking in geography through the emphasis on connections among actors. Overall, Ettlinger stresses the usefulness of governmentality as an analytical framework and mode of analysis that can be used to pose questions that are then answered through empirical inquiry. Crucial to this paper is the approach to space, 
multi-scalar analysis and context. Space is seen as relational and integral to governmentality. An example is the term 'governable spaces'. Governable spaces refer to processes in which a real and material governable world is composed (Rose 1999 cited in Watts 2004). A study by Watts on oil and power in the Niger Delta in Nigeria illustrates the production of governable spaces (Watts 2004). Watts observes how authoritarian governmentality is crucial to the production of governable spaces characterized by repression and violence. The federal government relies on various actors across different spatial scales to exert control over the spaces produced. Thus the production of governable spaces is crucial to understanding how the federal government intends to govern the population from a distance.

As noted earlier, scale is central to governmentality. It matters at what scale power is mobilized or targeted (Ettlinger 2011). This suggests a close association between scale and techniques of power. Drawing on Foucault (2000), Ettlinger presents techniques of power as rational schemas, sets of calculated and reasoned prescriptions which determine the institutions to be recognized, the spaces organized and behaviours regulated. Techniques of power arise from regimes of practices and related mentalities. Crucially, Foucault (2003) uses scale to distinguish between the different types of power, namely biopower, disciplinary power, pastoral power and modern power. Biopower encompasses the mechanisms or calculated courses of action directed at a population and thus is aimed at the macroscale, disciplinary power targets individuals making them to self-regulate in line with societal norms but also ensures the operationalization of biopower while pastoral and modern power target both (Ettlinger 2011). It can be deduced from the definitions that as scale increases, power is targeted to groups or populations. It is also important to note that techniques of power could be mundane turning to the use of little governmental techniques and tools such as brochures, maps, symbols and rituals (Rose et al. 2006; Ferguson and Gupta 2002). Mundane tools and practices are part of the creative process of the state by which the state promotes itself as a concrete overarching reality and also act as machines for convincing others (Ferguson and Gupta 2002).

Multi-scalar analysis as handled by Foucault means that it matters at what scale analysis begins and his framework favours ascending analysis which see mundane everyday practices as part of a macroscale societal project (Ettlinger 2011). The usefulness of scale in governmentality studies is confirmed in the aforementioned study by Watts (2004). Watts is particularly interested in the tensions between the different tiers of government in Nigeria and the resultant scale politics with each scale or governable space working against and in direct contradiction to one another. This scale politics draws attention to the internal scalar differentiation among national, regional and local governments (see Brenner 2004) and puts centralization, a process in which power is concentrated in a central authority (Mawhood 1993) and decentralization which entail the sharing of part of the governmental power with other tiers with each having authority within a specific area (Chikulo 1998) on the agenda. Along these lines, Simone (2010) adopts a governmentality approach to provide insights into the role of municipal governments in Africa and poses some interesting questions-what can be governed, who is to be governed and how the administration of cities actually takes place.

Foucault believes that power is not simply a matter of one actor dominating another (Foucault 1980 cited in Ettlinger 2011). Consistent with the notion that power is diffuse and the source is ubiquitous, resistance is seen as inevitable. As Jose (2010) points out, Foucault views resistance as intrinsic to the exercise of power. The imperfectness of the system and particularly the ineffectiveness of the techniques of power creates opportunities for individuals and groups to challenge norms, discourses and mentalities (Ettlinger 2011). Thus governmentality allows for spaces of resistance as power can always be challenged or resisted. Resistance is effected through power relations and a crucial task is to identify cracks in techniques of power that may provide spaces for resistance (ibid.). In Nigeria, the power of the federal government is always being challenged by different groups in spite of the adoption of authoritarian governmentality that tries to neutralize any opposition to authority (Watts 2004).

\section{Scale politics and spaces of resistance: the alliance and the politicization of funding}

Mega projects involve a multitude of actors spread over different scales and are expected to be 
accompanied by new forms of governing urban interventions (Swyngedouw et al. 2002). The multiplicity of actors involved implies that there is a need to maintain, reproduce or continuously work at the relations (Pieterse and Hyman 2014). Thus network relations are important to the success or failure of mega projects. The idea of transforming Lagos into a modern megacity through the LMCP came up when Bola Tinubu was the governor of Lagos State and Obasanjo the President of Nigeria. Following a meeting between the two on December 19, 2005, a 21 member Presidential Committee for the Redevelopment of Lagos Megacity Region was constituted (George 2009). The Region was made up of the local governments in Lagos and another four in neighbouring Ogun State. The Presidential Committee was charged with formulating policies and identifying problems related to security, traffic and transportation, water supply, land use planning, infrastructure development and maintenance, urban renewal and slum upgrading among others. The report of the committee, submitted to President Obasanjo in 2006 contained a range of recommendations on how the megacity region could be transformed into a world-class city by 2015 (Abiodun 2013). In order to facilitate the implementation of the LMCP, a decision was taken to create a special fund with contributions from the three major stakeholders, the federal, Lagos and Ogun state governments. Specifically, Lagos State was to contribute $40 \%$, Ogun State $30 \%$ while the federal government was to provide the remaining $30 \%$. Nigeria operates a three-tier system of government, federal (national), state (regional) and local. Thus under the LMCP, the federal government represented the national level while Lagos and Ogun states represented the regional level. The paper is particularly interested in how the LMCP in general and funding in particular became enmeshed in the political rivalries between the different tiers of government that made up the alliance. Borrowing from Rose et al. (2006), the LMCP raised critical questions such as who governs what and according to what logics? What techniques of power are used and to what ends? In order to fully address these questions we need to start by examining the conditions under which the LMCP emerged. The discussion begins with the position and significance of Lagos in the historical and national political context and the tensions and political struggles it has generated over the years.
The battle for Lagos

The status of Lagos as the national capital during the colonial era and its location in a particular geo-ethnic zone set the scene for a long history of opposition to the federal government and resistance politics (Adebanwi 2004; Moore 1984). Lagos was the seat of the federal government but its location in the southwest, a region controlled by the opposition meant it was a site of struggle between rival groups and political parties often based on regional and ethnic affiliations. In a reflection of Nigeria's regional divide, the Northern People's Congress (NPC) controlled the Northern Region, the National Council of Nigeria and the Cameroons (NCNC) the Eastern Region while the Action Group (AG) held sway in the Western Region. The federal government was dominated by the NPC and was in control of the federal territory of Lagos as carved out by the colonial government but the main opposition party, the AG as noted above controlled the Western Region with its influence extending to Lagos. Indeed in much of the country's history, the federal government was either dominated by a coalition of political parties with bases in the north or by a northern clique during military regimes (Fourchard 2011). Lagos remained the capital after independence in 1961 and the struggle for the control of the city continued. In the context of Nigeria's geo-ethnic politics, the common perception was that whoever controlled Lagos was in control of the country (Adebanwi 2004). It is therefore not surprising that a movement emerged with the aim of limiting the influence and role of Lagos in national politics. As Adebanwi observes, faced with opposition from the local political elite including the press, there emerged a pro-federal government group described as 'antiLagos elements' with agitations to relocate the national capital. In 1976, the military government of General Murtala Mohammed announced the decision to relocate the capital to Abuja in the geographic centre of the country. Several reasons were given for relocation including the lack of land for development but Moore (1984) sees the desire by the northern political elite to isolate themselves from their opponents in Lagos as a major motive. Another reason given for relocation was the desire to have a capital in a neutral place since Lagos was associated with a particular ethnic group (Adama 2007). This argument also favoured the northern political elite who saw 
Lagos as the hotbed of opposition (Fourchard 2011). Indeed the relocation of Nigeria's capital has been noted as an attempt by the federal government to address the challenge to its authority and a strategy aimed at controlling the entire population (Adama 2012). Even more important, the relocation of the capital has radically modified the space of public investments in Lagos due to a lesser commitment from the federal government (Fourchard 2011).

Between 1999 when democratic rule appeared on the political landscape following a long spell of military rule and 2015, Lagos had been governed by the opposition. Bola Tinubu who governed Lagos from 1999 and under whose leadership the LMCP was launched belonged to an opposition party, the Alliance for Democracy (AD). Fashola, who took over from Tinubu in 2007 and governed until 2015 belonged to an opposition party, the Action Congress of Nigeria $(\mathrm{ACN})$, the result of a merger between the $\mathrm{AD}$ and other opposition parties. There was however a dramatic change following the 2015 elections. Against all odds, the All Progressives Congress (APC) party, a grand coalition of opposition parties won the national elections on March 28 with General Buhari as the Presidential candidate. This was the first time in the history of Nigeria that a seating president (Goodluck Jonathan) and a ruling party; the People's Democratic Party (PDP) would lose an election. The APC retained its winning streak on April 11 in the governorship elections winning the majority of the 36 states in the country including Lagos. Lagos generated the most interest and anxiety for the two parties leading up to the elections. It was referred to as the crown jewel of the 2015 elections with the two parties engaged in a fierce battle over the city (Pulse 2015b). The reasons are obvious. Lagos may no longer be the national capital but it has retained its political significance for two main reasons. The city remains the economic nerve-centre of the country and has the largest population. A few days before the governorship elections, President Jonathan visited Lagos to solicit support for his party but the APC alleged he was in the city to perfect plans to rig the elections in favour of his party.

How can President Jonathan's 'legacy' endure when one of his last acts in office is a seeming vengeance mission to lead his party to capture Lagos, because the PDP sees the state as a cash cow that they can milk to death ... in their desperation over the Lagos election, they have shamelessly divided the people along ethnic, religious and regional lines ... (Lai Mohammed, National Publicity Secretary, APC cited in TheNews 2015).

The reference to Lagos as the 'cash cow' in the excerpt above is a pointer to its significance to the national economy as well as the finances of political parties. The role of Lagos in Nigeria's geo-ethnic politics is also noted in the allegation that President Jonathan had resorted to playing the ethnic, religious and regional cards. The PDP on its part accused the APC of planning to unleash violence and rig the elections in Lagos (Pulse 2015b). The new political dispensation brings with it interesting developments and implications for Nigeria and Lagos in particular which will no doubt attract the attention of researchers in the future. For the purposes of this paper, what is important is the legacy of Lagos as a site of conflict between the federal and Lagos State governments. The long history of opposition is manifested in partisan politics and disputes over the allocation of public resources and has contributed to the infrastructure crisis in Lagos (Fourchard 2011). This paper is interested in how opposition politics impacted the LMCP in particular.

Opposition politics and resource allocation

In Nigeria, the Federation Account (FA) serves as a pool for revenues accruing to the country. The revenue is largely from oil. The three tiers of government share the money that goes into the FA on a monthly basis. The Federal Accounts Allocation Committee (FAAC) is responsible for the distribution of the revenue. The current revenue allocation formula is Federal 52.7\%, State $26.7 \%$ and Local Government $20.6 \%$. In a country largely dependent on oil revenue, allocation from the FA represents a crucial source of funding. State governments plan their annual budgets largely based on allocations from the FA. The budgets allocate specific amounts to ministries and agencies to run their affairs. Mega projects call for changes in the priorities of public budgets (Swyngedouw et al. 2002). In Lagos there is a preference for infrastructure development as reflected in the state budget which allocates $60 \%$ to capital projects and $40 \%$ to recurrent expenditure. Lagos State spent N1 trillion (one trillion 
Naira) on 8, 961 projects between 2007 and 2015 in its drive to develop infrastructure (The Nation 2015).

Federal allocations are crucial but the management of the FA is highly politicized. Interestingly, the most vocal critics of the federal government for the way it handles the FA belong to opposition parties. For example, the governor of Lagos State, Fashola made an un-scheduled appearance at the State House of Assembly where he registered his worry over the dwindling monthly federal allocation to states and the federal government's uncoordinated fiscal policies (BusinessDay 2014). Rotimi Amaechi, the governor of Rivers State was another notable critic of the federal government's handling of the FA. Ameachi used to belong to the same party as the President but later joined the opposition party and became one of the President's fiercest critics. On the management of the FA, he went as far as accusing the President of favouring Bayelsa State (the President's state) over Rivers (Owete 2013). The majority of states in Nigeria are almost entirely dependent on the FA but Lagos has the enviable record of the state with the most Internally Generated Revenue (IGR). In 2008, IGR accounted for $61.06 \%$ and increased to $63.60 \%$ in 2012 (Debt Management Office, 2014). The state government attributes the success in IGR to a high level of fiscal responsibility on its part in contrast to what it notes as the imperfections in the fiscal federalism as currently being practiced. According to state officials, most of the IGR comes from Personal Income Tax, licenses, fines and sale of assets. Crucially, the high rate of IGR translates into less dependence on federal allocations and more political leverage for Lagos State. It is fair to suggest that the relative financial independence enjoyed by Lagos State has helped to sustain the history of opposition politics and ultimately played a part in shaping relations between the federal and Lagos State governments under the LMCP. The contentious relationship and the lingering suspicion of the federal government often came to the fore during interviews with state officials. An interesting example is the allegation that the federal government tend to deliberately work against Lagos State in situations that involve negotiations with a third party such as the World Bank. If true, it confirms the observation made by Watts in his study in Nigeria that each scale or governable space tend to work against each other (Watts 2004).
Resource allocation also provides an opportunity to examine the spaces of resistance. The evolution and role of local governments in Nigeria make interesting reading but the discussion here is limited to how local governments feature in the contentious relations between the federal and Lagos State governments. Local governments feature prominently in the attempt by the Lagos State Government to resist the power of the federal government. It begins with a highly politicized issue, the number of local governments in a state. It may sound innocuous but it is important because the more the number of local governments in a state, the more money from the FA. In 2003, the then governor of Lagos State Bola Tinubu made the decision to create 37 more local governments. The action was seen as a way of getting more revenue from the FA and as a protest against the centralization of tax revenues (Fourchard 2011). For Lagos State officials, more local governments mean getting back some of the tax revenue which they see as being illegally taken by the federal government. Beyond the financial gains, the creation of more local governments is also linked to the politics of national census. For example, the 2006 census gives Kano State a higher population than Lagos State contrary to figures from the UN and others. According to Fourchard (2011), Lagos politicians argue against Kano State being given a higher figure and see the creation of more local governments as a way of addressing the injustice. To no great surprise, the decision of the Lagos State Government to create more local governments was deemed unconstitutional by Obasanjo who was the president at the time. Obasanjo went on to withhold the statutory allocations meant for local governments in Lagos as punishment. The issue was resolved in 2005 but it seriously affected the capacity of the state government to provide basic services and infrastructure.

\section{The LMCP: A new beginning?}

The federal and Lagos State governments did share a common desire to transform Lagos into a megacity. President Obasanjo's support was crucial at the early stages but as noted earlier he had a highly contentious relationship with BolaTinubu, the governor of Lagos State at the time. They not only represented different tiers of government and the tensions that come with it but also belonged to different political parties. The two were often at odds with each and fought what can be 
described as very personal battles on the pages of newspapers. It was not long before the "war of supremacy and muscle-flexing exacerbated by different ideologies" between the federal government and the Lagos State Government (LSG) led to the recall of the professional staff and grounding of activities of the LMCP (Abiodun 2013, p. 4). Furthermore, the LMCP became enmeshed in the country's longstanding debate over the apportioning of powers and fiscal responsibilities and the distribution of functions between the different tiers of government. Nigeria has adopted federalism, a system which emphasizes the non-centralization of powers but the concentration of power at the centre remains a major feature of governance (Adama 2007). Obasanjo in particular has been accused of being disdainful of federalism and running a military command structure in which state (regional) governments were treated as his prefects (Elaigwu 2007). It is therefore easy to see why the federal government tried to dominate the implementation of the LMCP. One of the recommendations of the Presidential Committee was the setting up of a tripartite institutional arrangement made up of the President's Council, Mega City Intergovernmental Committee and the Mega City Transportation and Planning Authority. This was approved by the federal government but it went further to set up the Lagos Mega City Development Authority (LMCDA) chaired by the renowned Nigerian geographer and urban planner Professor Akin L. Mabogunje. Abiodun (2013) observes three major contentious issues that subsequently arose. The first was the chairmanship position of the LMCDA. There was a tussle between the federal and Lagos State governments as to who should carry out the appointment. The second was the desire of the Lagos State Government to have $60 \%$ membership of the board of the LMCDA which the federal government objected to. The third centred on how the board and LMCDA should be run and financed. The Lagos State Government proposed that the federal government provide a special grant but should not be actively involved in the day-to-day running of the institutions. The federal government was not favourably disposed towards the suggestion. All these contributed to the subsequent withdrawal of the federal government from the LMCP. The implications for funding are obvious. It meant the loss of the $30 \%$ expected to come from the federal government as contained in the initial agreement.
The feud that accompanied the LMCP also extended to the relations between Lagos and Ogun state governments largely due to partisan politics. That the Lagos Megacity Region extended to four local governments in neighbouring Ogun State was an acknowledgement that Lagos had grown beyond its borders. Over the years, the resultant urban sprawl had caused tensions between the two states. It was therefore no surprise that the planners of the LMCP decided to revisit the issue. The Presidential Committee was given the task of reviewing the implementation of a 1981 technical report on common border problems between the two states (George 2009). The committee was to go further and identify the role and responsibilities of key stakeholders in the two states and recommend institutional and legal frameworks. Under the LMCP, the two states were to cooperate on a range of issues of common concern including the dredging of dams and the funding of joint projects. However, it soon became apparent that cooperation would be difficult to achieve. The governors of Lagos and Ogun states belonged to different political parties at the time. The Ogun State governor was a member of the PDP, the ruling party at the national level while Lagos was under the opposition party. In the end, as one Lagos State official put it, 'the idea of collaboration was abandoned entirely due to politics'. This meant that the LMCP lost another major source of funding and the grand alliance completely unraveled.

In summing up, it is important to say something about the role of local governments if we are to have a comprehensive and grounded understanding of how Nigeria is governed and particularly how city administration takes place and the implications for projects such as the LMCP. That local governments have not featured in the discussion except as pawns in the fights between the federal and Lagos State governments is testament to their highly marginal role in urban governance. The global norms of governance dictate that local governments be responsible for urban governance and local economic development. In Ontario, Canada, municipalities have the authority and responsibility to provide basic services and to develop infrastructure (Cleave and Arku 2015). In Nigeria, the usurpation of local functions by higher tiers is a notable and largely acceptable practice (Adama 2007). The justification is based on the logic that a strong federal government is better suited to govern a fractious and highly divided society such as 
Nigeria. In many cases local governments exist in name only having been stripped of their constitutional rights. However, as noted earlier, mega projects are expected to be accompanied by a restructuring of the state and new relations between state institutions. We have already observed that there were no changes in the relations between the federal and Lagos State governments but did the LMCP bring about any changes in the role of local governments in Lagos? According to local government officials, their traditional functions are limited to managing Primary Health Care (PHC), primary schools and markets; construction of culverts and drainages; installation and maintenance of street lights; recording of births and deaths; naming of streets and house numbering. The situation remains unchanged after the LMCP. The management of the Federation Account (FA) provides an interesting insight into the very marginal position of local governments. Like states, local governments are heavily dependent on federal allocations. However, unlike states, they do not receive the allocations directly from the Federal Accounts Allocation Committee (FAAC). The money goes to the Joint Accounts Committee (JAC) made up of the Accountant General of the Federation (representative of the federal government), the commissioner for local government (representative of the state governments) and chairpersons of local government councils (representative of the local governments). The process leaves room for manipulation. According to local government sources, JAC was set up as response to the purported misuse of funds by local governments. The result is that local governments have little or no say over how much they receive and what the money is spent on. JAC has the authority to deduct money to be spent on joint expenses, that is projects or areas where all local governments in a state are expected to contribute. The balance is then shared among the local governments based on criteria that are not often clear. Local governments have opposed the creation of JAC over the years due to the lack of autonomy and limited responsibilities associated with it but with little success. In an interesting development, according to local government officials, there were calls by some delegates at a National Conference convened by President Jonathan in March 2014 to address various national issues to scrap local governments. In response, members of the National Union of Local Government Employees (NULGE) stormed the venue of the conference to protest the move. The development suggests that the marginal position of local governments is not about to change.

\section{Public-private partnerships under the LMCP}

The concrete of Lagos defines its aspirations but ultimately works as the substrate for the city population to appropriate and redefine notions of modernity ... The city is being rediscovered and revealed, however, as the Lagos state administration reasserts its claim to the public realm through interventions of landscape beautification ... led by the current administration of Babatunde Fashola, the city has become the laboratory for a series of public-private initiatives established in the last decade to deliver urban services ... Thus the city is emerging as the site where the citizen is being re-engaged, as municipal authorities seek to regain their trust and perhaps instil wider aspirations to make Lagos the most dynamic megacity in subSaharan Africa (Omezi 2014: 112).

The above excerpt reveals the desire of the Lagos State Government to embrace modernism in the bid to make Lagos a more attractive city. Mega projects take place within limited state capacity and provide useful avenues for infrastructure development through private capital (Swyngedouw et al. 2002). The focus on PPP and infrastructure development as the most viable means of transforming Lagos into a modern megacity is explicitly stated in the excerpt. The amount needed for infrastructure development in Lagos in the next ten years is estimated at USD50 billion (Chima 2013). Historically, the government has borne the largest share of infrastructure financing accounting for $80 \%$ with multilateral and bilateral agencies providing $12 \%$ and private institutions only $8 \%$ (SNC-LAVALIN 1995). The LMCP provided an opportunity to address this "imbalance" as referred to by state officials. A major argument is that the resources of the government is insufficient to deliver the modern megacity it desires without augmenting with private sector resources. In addition, state officials pointed to the benefits that would come with private sector participation such as innovativeness and managerial efficiency. Thus the LMCP's Presidential Committee 
was mandated to give advice on private sector participation in infrastructure and service delivery. Subsequently, the public-private partnership (PPP) model was adopted to bridge the huge deficit in infrastructure financing. The Lagos State PPP office was set up in 2008 to promote, develop and monitor infrastructural projects. Some of the key functions are the provision of technical assistance to government agencies, evaluation and monitoring of PPP initiatives. The Lagos State Public Private Partnership Law 2011 and the Public Procurement Law 2011 were enacted to facilitate PPP. There is also a 'Lagos State Investment Handbook' which is a guide to potential Nigerian and international investors on the current laws, policies, regulations, opportunities and incentives to doing business and investing in the city (see Lagos State Government 2012). Other notable initiatives pointed out by state officials include a tax holiday in some industrial clusters such as the Lekki Free Trade Zone; the provision of land subsidy for affordable housing; political support for PPPs; and good legal and regulatory framework.

The PPP model as adopted by the government entails the allocation of roles based on the ability or capacity of each party and who is most suited to bearing certain risks. Based on these, the functions allocated to the private sector include provision of technical skills and support, provision of capital, operations and management, maintenance and innovation and creativity to enhance service delivery. The state is expected to monitor, act as a regulator to ensure the private sector complies and make financial contributions when required. The government acknowledges that while the two parties take on traditional roles, there are situations where roles may shift based on negotiations. Furthermore, there are sanctions in line with the penalty in the concession agreement when a party fails to perform. When necessary, a private firm is given a 'grace' period and the terms and conditions are reviewed and adjusted. If the partner is not satisfied, the contract is then terminated. The major types of private sector participation adopted by the government are build operate transfer (BOT); build own operate (BOO); long term lease, joint venture, and operation and management concession. There are a number of ongoing PPP projects. Roads are accorded high priority. The USD300 million Lekki-Epe Expressway project is a partnership between Lagos State Government and the Lekki Concession
Company (LCC). In a country where uninterrupted electricity supply remains a dream, power generation is also receiving a lot of attention. Four independent power plants have been delivered through PPP including a plant providing electricity to the Lagos State Government secretariat and another to Shomolu where much of the printing in the city takes place. The Bus Rapid Transit and ferry services, the Lekki-Ikoyi Link Bridge and various housing complexes are other notable PPP projects. Shopping malls are also springing up across the city. An example is the shopping complex at Tejuosho market, being built by Sunbaya Engineering firm with First Bank Nigeria Limited providing the finance. The bank is to manage the project through a Facility Manager until it reverts back to the government after 15-25 years. However the project has been facing problem of funding and had fallen behind schedule. Furthermore and in a reflection of a global phenomenon, the Chinese are playing an increasing role in infrastructure financing and development in Lagos. A consortium of Chinese firms is visible at the Lekki Free Trade Zone under a joint venture. The Chinese are also involved in a light rail transport network started during the regime of Jakande who was governor of Lagos State from 1979 to 1983. The project was later abandoned but has been revamped through a partnership arrangement. However there are some problems associated with Chinese firms. State officials point to the tendency of the Chinese to delay projects, occupy all management positions, overwork the indigenous staff and pay them salaries not commensurate with the work they put in. There is also the language barrier which makes communication between the Chinese and the local staff difficult.

Overall, state officials describe their relationship with private firms as cordial. They also point to a number of gains of PPP such as employment generation and skill acquisition but acknowledge some challenges. PPP is a relatively new phenomenon in Lagos. The result is limited public knowledge and understanding of PPP. According to state officials, there is a lot of doubt and apprehension on the part of the people about the potency and credibility of PPP as a viable tool for the delivery of public infrastructure. For example, some motorists do not understand why they should pay tolls on the designated highways. Beyond this, there is the general problem of funding. A major aspect is a weak local financial market. Local 
banks lack the capacity to fund large PPP projects hence a greater reliance on foreign lenders and investors which comes with the attendant risks of exchange rate fluctuations. Furthermore, sometimes companies underestimate the amount of capital required for a project or lack an understanding of the scope of work. Investor's confidence is another issue. The problem is tied to the history of doing business in Nigeria as a whole. According to state officials, Nigeria has breached some agreements in the past and this has impacted negatively on investor confidence. As a result, in many cases, investors insist on taking extra precautions before making a commitment. The Eti-Osa Lekki Epe Expressway Road was cited as an example of a case where the investors asked for further guarantees on their investment. Political instability was also cited as a major problem. A change in government at the state level may lead to the abandonment of projects because the in-coming government is unwilling to fund projects initiated by the previous one. Finally, there is the familiar problem of affordability. This is crucial since it influences the choice of infrastructure to be built. The decision to initiate a PPP project in a place may depend on the ability of the people to pay for the service. There are cases where the government realizes that a particular infrastructure or service is needed but will not take any action if it feels the economic power of potential users is low. In some cases, the government is forced to provide subsidies if a shortfall arises after the infrastructure has been built. For example, the financial agreement reached for the Eti-Osa Lekki Epe Expressway allows for indexing of inflation every 3 months but the government has been prevailing on the private company not to increase the toll paid by motorists and have instead agreed to pay subsidies. Related to the problem of affordability is the tendency for private firms to be more interested in projects that will yield huge financial returns. The Eko Atlantic City discussed below is an example.

\section{What gets funded: the Eko Atlantic City Project}

The Eko Atlantic City project is an impressive albeit ambitious urban development project involving the construction of a new city. The project confirms the notion that the proliferation of mega projects is an indication of a trend towards the privatization of urban and regional planning as private developers take centre stage in the planning, development and regulation of urban spaces (Shatkin 2011, p. 78, emphasis original). It was initiated by a private firm, South Energyx Nigeria Limited, a subsidiary of Chagoury and Chagoury, a company owned by a group of brothers of Lebanese origin. The process began in 2003 with a feasibility study conducted by the company and a consortium of international professionals. Thereafter, South Energyx approached the state government with the idea of building a new city and submitted a proposal which was later approved. The company was given incentives such as legal backup, tax wavers and a pledge by the government that it would not ask for any financial payments until the company started making returns on its investment. South Energyx has a concession to develop, own and manage the land for 78 years. The desire by governments and developers to mobilize corporate entrepreneurship and technology and create spaces to attract investments is a common feature of mega projects (Shatkin 2011). The multi-billion dollar Eko Atlantic City project is to be financed entirely through private investments. A host of local and foreign financial institutions including First Bank, Guaranty Trust Bank and Access Bank all based in Nigeria and BNP Paribas (France), KBC Bank (Belgium) are involved.

Eko Atlantic City was officially launched on February 21, 2013 with Jonathan, the Nigerian President, Fashola, the Governor of Lagos State and former United States President Bill Clinton in attendance. The launch had some symbolic value. It provided the government and the developers with an opportunity to sell a modernist and romantic vision of the city with the ultimate aim of attracting private capital. The presence of high profile dignitaries suggest a 'seal of approval' likely to attract potential investors. Officially, climate change was cited as a central motivation for the Eko Atlantic City project. In his remarks, President Clinton noted that the project will create enormous opportunities and improve the economy of Nigeria but even more crucial, is a response to climate change (Akinsanmi 2013). In terms of the environmental credentials, one of the much talked about achievements is that Eko Atlantic City is being built on land reclaimed from the Atlantic Ocean. A Belgian company is responsible for the dredging. By November 2013 when the author visited the site, about five million square metres had been 
reclaimed. Furthermore, Lagos is located on the Atlantic coast and has faced problems of flooding and coastal erosion over the years. The Bar Beach in particular has witnessed rapid erosion. From the early 1950s to the 1990s, about N37.5 billion ( 37 billion, 500 million Naira) was spent on the restoration of the beach (Awolaja 2010). A major aim of the government under the LMCP is to tackle the problems of flooding and erosion. The ministry of Waterfront Infrastructure Development was created in 2007 as part of the government's efforts to protect the over $180 \mathrm{~km}$ of shoreline that Lagos has. According to government sources, one of the reasons South Energyx was chosen was the depth of its financial and technical solutions to the problem of Bar Beach erosion. Notably, the Eko Atlantic City project entails the construction of the 'Great Wall of Lagos' meant to check shore-line erosion and flooding. The Wall is $8 \mathrm{~km}$ long and will consume about 100,000 concrete blocks weighing 5 tons each.

Not everyone is impressed with the climate change credentials of Eko Atlantic City. The government and developers have been accused of exploiting the crisis of climate change to increase inequality and seal themselves from its impacts. Lukacs (2014) believes that the real inspiration for Eko Atlantic City comes from rampant capitalism and instead of addressing climate change will in fact have negative implications for the environment as a result of the unfettered accumulation and consumption that would come with it.

\begin{abstract}
The disaster capitalists behind Eko Atlantic have seized on climate change to push through procorporate plans to build a city of their dreams, an architectural insult to the daily circumstances of ordinary Nigerians ... Eko Atlantic is where you can begin to see a possible future-a vision of privatized green enclaves for the ultra rich ringed by slums lacking water and electricity (Lukacs 2014, p. 3).
\end{abstract}

There is every reason to believe that the project will reinforce socio-spatial exclusion. SouthEnergyx expects to recoup its investments largely from the sale of plots. The minimum size of plot for sale is $3000 \mathrm{~m}^{2}$ and the prices vary according to location. Plots along the waterfront attract the highest prices at USD $2500 / \mathrm{m}^{2}$. Those along major roads cost USD 1500 while landlocked plots go for USD1250. It is instructive that the prices are quoted in US dollars and not the local currency. Crucially, in a city where $70.24 \%$ are described as poor (National Bureau of Statistics 2009), it is fair to say that the majority of Lagosians are not welcome in Eko Atlantic City. When confronted, state officials disputed the allegation that the project is elitist and pointed to a number of gains for all residents, including the poor. They argue that the money that would be made from the project will be used to create new infrastructure or upgrade existing ones around Lagos. A related argument is that since the government is not spending any money, funds would be diverted to other sectors that would benefit the poor. Furthermore, the city is planned to house 250,000 residents and will make provisions for another 150,000 commuters largely made up of people that are expected to work there. Thus another benefit pointed out by officials is that the project will generate employment. The notion that elitist projects are accompanied by benefits that would somehow trickle down to the poor is a common one even though there is little evidence to support it (see Swyngedouw et al. 2002).

Mega projects "represent a vision for the transformation of the urban experience" (Shatkin 2011, p. 77) Thus they are often imbued with modernist underpinnings bordering on utopia. In Royston (UK), the business improvement district (BID), a PPP project had 5 years to fulfil the major objective of "transforming the look and feel of the town, reversing the negative image, increasing footfall, spend and dwell time (Royston 2008: 2 cited in Ward 2011, p. 72). Particularly in the South, infrastructure projects provoke deep affectual commitments and governments copy projects so they can take part in a "contemporaneous modernity" by replicating projects from elsewhere to "participate in a common vision and conceptual paradigm of what it means to be modern" (Larkin 2013, p. 333). In Lagos, according to state officials the priority given to PPP and rapid infrastructure renewal and upgrade by the government fits into the overall objective of providing commensurate infrastructure to an increasing population and achieving the vision of making Lagos Africa's model modern megacity and an economic and financial hub that is safe, secure, functional and productive. As is the practice with such mega projects (see Shatkin 2011), Eko Atlantic is conceived as a self-contained urban entity made up of commercial, residential and office 
districts among others. Ultimately, Eko Atlantic City aims to provide a luxurious urban lifestyle. The residential district is to have an open, modern feel with many facilities and attractions aimed at tourists including a water park, theatres, cafés and restaurants. There would be skyscrapers rising up to 35 floors, an eight lane two kilometer boulevard, tree-lined streets and luxury apartments, roads, bridges and underground parking. The city is also being promoted as a business haven. The business district is likened to the Champs-Élysées in Paris or Fifth Avenue in New York and is being promoted by the developers as the future headquarters for African entrepreneurship. The strategy is paying off as by December 2014, all the plots in phase 1 had been sold off. Oil companies and banks are buying plots in order to build offices. The first office complex to be built is the 15 floor company headquarters of Afren Plc, an international energy company listed on the London Stock Exchange. Another oil and gas company, Orlean Invest Holding bought $400,000 \mathrm{~m}^{2}$ of land. Ultimately, Eko Atlantic City is one step towards the realization of the dream of making Lagos a modern megacity. However, it remains to be seen if the ambitions of the government and developers will be realized but already it seems the promised luxurious urban lifestyle is not for all Lagosians.

\section{Conclusion}

Like many other cities across the globe, Lagos is striving to reinvent itself as a modern city and a destination for global capital. The LMCP underlies the popular notion that infrastructure plays a crucial role in stimulating local economic growth and in realizing the dream of a modern city. Adequate finance is crucial to the success of mega projects and ultimately to the aim of reinventing Lagos as a financial haven and a modern city. Using the LMCP as a case study, the paper paid particular attention to how capital is mobilized, the kinds of alliances or networks found and the types of infrastructure that is prioritized. In line with neoliberal thinking, capital was to be mobilized largely from the private sector but in a climate of limited private investments, public funds was necessary at the initial stage to facilitate the implementation of the project. This led to an alliance between the federal government and Lagos and Ogun state governments. However, the complex and inherently political nature of urban infrastructure development raised fundamental issues that subsequently shaped the alliance. The members of the alliance represent different tiers of government. Adopting a governmentality approach, the paper discussed the workings of the alliance in the context of historical and national political processes. Lagos occupies an important position in the broader societal and state project. Over the years, the city had been a site of conflict and power struggle between the federal government and Lagos State Government with each laying claim to the city. Furthermore, there is the longstanding problem of the apportioning of fiscal and political responsibilities and the distribution of functions between the different tiers of government. The federal government has sought to exercise its authority and exert control over the national territory by usurping the power of the lower tiers of government. In the language of governmentality, the practices observed in the LMCP can be seen as part of a macroscale societal project, that is, an attempt to create governable spaces and govern from a distance. It soon became evident that the federal government sought to control the implementation of the LMCP. Disputes emerged with the Lagos State Government over who was responsible for what. Beyond this, a history of opposition politics and a highly politicized resource allocation system made cooperation particularly difficult and contributed to the unraveling of the alliance. As is often the case, the desire to control opens up spaces of resistance. Once more drawing from a governmentality approach, scale features prominently in not only how power is mobilized, who is targeted, the techniques used but also how power is resisted. All these are reflected in the decision of the Lagos State Government to create additional local governments. The move can be seen as an attempt by a lower tier of government to take back power from a higher tier. The actions of the Lagos State Government is based on the rational that local governments are under its direct control. Thus additional local governments equates more powers and financial resources. Furthermore, partisan and opposition politics opened up spaces for the Lagos State Government to resist the power of the FG as demonstrated in events related to the Federation Account, an important source of funding.

The subsequent withdrawal of the federal and Ogun State governments from the LMCP made private capital even more crucial to the success of the project. 
The Lagos State Government embarked on an intensive drive to attract private capital and adopted the PPP framework. The logic behind PPP centred on the need to use private capital for mega infrastructure projects and hence free up public funds for other uses, a recognition of private firms for their technical expertise, innovative skills and efficiency. However, the paper observed a number of challenges. The rate of private investments especially from local firms remains relatively low, there is limited support from the public and low investor confidence and political instability pose additional problems. Crucially, the preference for huge infrastructure and elite projects such as the Eko Atlantic City is further reinforcing socio-spatial exclusion.

At the broadest level, the paper has shown how modernist projects can be fractured by specific ideologies and practices. Mega projects call for a restructuring of the state accompanied by new relations. Under the LMCP, the federal and Lagos State governments both shared the dream of transforming Lagos into a modern city but the anticipated new relations meant to realize the dream did not materialize. To the contrary, we observed an ideology and rationality of government which seeks to preserve or maintain existing spaces characterized by highly contentious relations of power. With regards to what gets prioritized under PPP, we noted the practice of a preference for elite projects such as the Eko Atlantic City. With a private company driving the project and private investments at the core, it exemplifies the neoliberal vision of re-orientating urban governance away from the state. Crucially, the proposed city bears the hallmarks of modernism as it entails the physical transformation of the urban environment and promises its inhabitants a good quality of life. However, it is targeting big multinational corporations and elites. Thus Eko Atlantic City is limiting the modern urban experience to a very tiny segment of the population and confirms the persistent inequalities that accompany neoliberal and modernist projects or what Gandy (2006) refers to as 'incomplete modernity'.

Acknowledgements Funding was provided by Swedish International Development Cooperation Agency (Grant No. SWE-2011-195).

Open Access This article is distributed under the terms of the Creative Commons Attribution 4.0 International License (http://creativecommons.org/licenses/by/4.0/), which permits unrestricted use, distribution, and reproduction in any medium, provided you give appropriate credit to the original author(s) and the source, provide a link to the Creative Commons license, and indicate if changes were made.

\section{References}

Abiodun, J. O. (1997). The challenges of growth and development in metropolitan Lagos. In C. Rakodi (Ed.), The urban challenge in Africa: Growth and management of its large cities. Tokyo: United Nations University Press.

Abiodun, Y. (2013). Metropolitan planning for Lagos mega city. http://wwwngrguardiannews.com/columnist/126500abiodun-metropolitan-planning. Accessed 1 July 2014.

Adama, O. (2007). Governing from above: Solid waste management in Nigeria's New Capital City of Abuja. Stockholm studies in human geography, 17. Stockholm: Almqvist and Wiksell International.

Adama, O. (2012). State, space and power in Postcolonial Africa: Capital relocation as a state building project in Nigeria, Hemispheres, no. 27.

Adebanwi, W. (2004). The city, hegemony and ethno-spatial politics: The Press and the struggle for Lagos in Colonial Nigeria. Nationalism and Ethnic Politics, 9(4), 25-51.

Akinsanmi, G. (2013). Clinton: Eko Atlantic City, destination for global investment. http://www.thisdaylive.com/ articles/clinton-eko-atlantic-city. Accessed 9 March 2013.

Ali, K. A., \& Rieker, M. (2008). Introduction urban margins. Social Text 95, 26(2).

Amin, A. (2006). The good city. Urban Studies, 43(5/6), 1009-1023.

Awolaja, K. G. (2010). Management of coastal area lands in Lagos State of Nigeria-An emerging market perspective. http://www.propertyfinance.it. Accessed 9 July 2014

Brenner, N. (2004). New state spaces: Urban governance and the rescaling of statehood. Oxford: Oxford University Press.

Brown, A., Lyons, M., \& Dankoco, I. (2010). Street traders and the emerging spaces for urban voice and citizenship in African cities. Urban Studies, 47(3), 666-683.

BusinessDay. (2014). Dwindling federal allocation to states. http://businessdayonline.com/2014/03. Accessed 7 July 2014.

Caldeira, T. P. R. (2008). From modernism to Neoliberalism in São Paulo: Reconfiguring the city and its citizens. In A. Huyssen (Ed.), Other cities, other worlds: Urban imaginaries in a globalizing age. Durham, NC: Duke University Press.

Chikulo, B. C. (1998). Decentralization and the role of the state in the future. In I. Mandaza (Ed.), Governance and human development in Southern Africa. Harare: SAPES Books.

Chima, O. (2013). Fashola: Lagos requires $\$ 50$ bn for infrastructure devt. ThisDay. http://www.thisdaylive.com/ articles/fashola-lagos-requires-50bn-for-infrastructure-de. Accessed 13 November 2013.

Cleave, E., \& Arku, G. (2015). Place branding and economic development at the local level in Ontario. Canada. GeoJournal, 80(3), 323-338. 
Cochrane, A., \& Ward, K. (2012). Researching the geographies of policy mobility: Confronting the methodological challenges. Environment and Planning A, 44(1), 5-12.

Cossou, E. (2010). Lagos aims to be Africa's model megacity. www.newsbbc.co.uk/2/hi/business/8473001.stm. Accessed 8 August 2015.

Crossa, V. (2009). Resisting the entrepreneurial city: Street vendors' struggle in Mexico city's historic center. International Journal of Urban and Regional Research, 33(1), 43-63.

Dean, M. (2010). Governmentality power and rule in modern society. Los Angeles, CA: Sage.

Elaigwu, J. I. (2007). Federalism, governance and security. Paper presented at the conference Evangelische Akademie Loccum, 15-17 June 2007 in Berlin.

Ettlinger, N. (2011). Governmentality as epistomology. Annals of the Association of American Geographers, 101(3), 537-560.

Fainstein, S. S. (2008) Mega-projects in New York, London and Amsterdam. International Journal of Urban and Regional Research. doi:10.1111/j.1468-2427.2008.00826.x.

Ferguson, F., \& Gupta, A. (2002). Spatializing states: Towards an ethnography of neoliberal governmentality. American Ethnologist, 29(4), 981-1002.

Filani, M. O. (2012). The changing face of Lagos: From vision to reform and transformation. Brussels: Cities without Slums. http://www.citiesalliance.org/sites/citiesalliance. org/files/lagos-reform-report. Accessed 7 September 2013.

Forrer, J., Kee, J. E., Newcomer, K. E., \& Boyer, E. (2010). Public-private partnerships and the public accountability question. Public Administration Review, 70(3), 475-484.

Foucault, M. (1980). Two lectures. In C. Gordon (Ed.) Power/knowledge: Selected interviews and other writings 1972-1977 (trans: Gordon, C., Marshall, L., Mepham, J., \& Soper, K.) (pp. 78-108). New York, NY: Pantheon.

Foucault, M. (2000). Questions of method. In J. D. Faubion (Ed.), Michel Foucault/power (trans: R. Hurley and others) (pp. 223-238). New York, NY: The New Press.

Foucault, M. (2003). Society must be defended: Lectures at the Collège de France, 1975-1976. In M. Bertani, \& A. Fonatana (Eds.) (trans: Macey, D.). New York, NY: Picador.

Fourchard, L. (2011). Lagos, Koolhaas and partisan politics in Nigeria. International Journal of Urban and Regional Research, 35(1), 40-56.

Freund, B. (2010). Is there such a thing as a post-apartheid city? Urban Forum, 21(3), 283-298.

Gandy, M. (2005). Learning from Lagos. New Left Review, 33, 37-52.

Gandy, M. (2006). Planning, anti-planning and the infrastructure crisis facing metropolitan Lagos. Urban Studies, 43(2), 371-396.

George, C. K. (2009). The challenges of urbanisation in Nigerian Urban Centres: The Lagos Mega-City Situation-a town planner's perspective. Lagos: Spectroplan Konsult Ltd.

Godlewski, J. (2010). Alien and Distant: Rem Koolhaas on Film in Lagos, Nigeria. TDSR, XX1(11).

Graham, S. (2011). Disruptions. In M. Gandy (Ed.), Urban constellations. Berlin: Jovis Verlag GmbH.
Hall, T., \& Hubbard, P. (1996). The entrepreneurial city: New urban politics, new urban geographies? Progress in Human Geography, 20(2), 153-174.

Home, R. (2013). Of planting and planning: The making of British colonial cities. London: Routledge.

Ilesanmi, A. O. (2010). Urban sustainability in the context of Lagos mega-city. Journal of Geography and Regional Planning, 3(10), 240-252.

Jose, J. (2010). A (con)fusion of discourses? Against the governancing of Faucault. Social Identities, 16(5), 689-703.

Kirkpatrick, C., \& Parker, D. (2004). Infrastructure regulation: Models for developing Asia. ADB Institute research paper series no. 60. Japan: Asian Development Bank Institute.

Debt Management Office. (2014). Revenue, expenditure and debt profile, a sustainable fiscal trend. Lagos: Lagos State Ministry of Finance.

Lagos State Government. (2012). Lagos State investor handbook: A guide to business and investment in Lagos State. http://www.lagosstate.ppp.gov.ng/resources/documents/ LagosStateInvestorHandbook.pdf. Accessed 2 July 2014.

Larkin, B. (2013). The politics and poetics of infrastructure. Annual Review of Anthropology, 42, 327-343.

Lefebvre, H. (1996). Writings on cities. In E. Koffman, \& E. Lebas (Eds.) (trans: Koffman, E., Lebas, E.). Oxford: Blackwell.

Lindell, I., Hedman, M., \& Nathan-Verboomen, K. (2010). The World Cup 2010 and the urban poor 'World class cities' for all? Policy Note 2010/5, Nordiska Afrikainstitutet. Uppsala: Nordiska Afrikainstitutet.

Lukacs, M. (2014). New, privatized African city heralds climate apartheid. http://www.theguardian.com/environment/truenorth/2014/jan/21.

Mawhood, P. (1993). Decentralization: The concept and the practice. In P. Mawhood (Ed.), Local government in the Third World: The experience of decentralization in tropical Africa. Chicester: Wiley.

McCann, E., \& Ward, K. (2011). Urban assemblages: Territories, relations, practices, and power. In E. McCann \& K. Ward (Eds.), Mobile Urbanism: Cities and policy making in the global age. Minneapolis: University of Minnesota Press.

McFarlane, C., \& Rutherford, J. (2008). Political infrastructures: Governing and experiencing the fabric of the city. International Journal of Urban and Regional Research, 32(2), 363-374.

Mitchell, D. (2003). The right to the City: Social justice and the fight for public space. New York, NY: Guilford Press.

Moore, J. (1984). The political history of Nigeria's New Capital. The Journal of Modern African Studies, 22(1), 167-175.

National Bureau of Statistics. (2009). Nigeria-Harmonised Nigeria Living Standard Survey 2009, First Round. Abuja: National Bureau of Statistics/Federal Government of Nigeria.

Omezi, G. (2014). Lagos: City of concrete. In M. Gandy (Ed.), Urban constellations. Berlin: Jovis Verlag GmbH.

Ong, A. (2011). Introduction worlding cities, or the art of being global. In A. Roy \& A. Ong (Eds.), Worlding cities asian experiments and the art of being global. Oxford: Blackwell.

Owete, F. (2013). Presidency slams Amaechi, says he is pretending to be Rivers" "Messiah". Premium Times, 
November 28, 2013. www.premiumtimesng.com/news/ 150514.

Pessoa, A. (2008). Public-private partnerships in developing countries: Are infrastructures responding to the New ODA Strategy? Journal of International Development, 20(3), 311-325.

Pieterse, E., \& Hyman, K. (2014). Disjunctures between urban infrastructure, finance and affordability. In S. Parnell \& S. Oldfield (Eds.), The Routledge handbook on cities in the global south. London: Routledge.

Pulse. (2015a). Nigeria elections 2015: APC planning to rig Lagos polls,' PDP alleges. http://pulse.ng/politics/nigeriaelections-2015-apc-planning-to-rig-Lagos. Accessed 14 April 2015.

Pulse. (2015b). Nigeria Elections 2015: The battle for the soul of Lagos begins. http://pulse.ng/politics/nigeria-elections2015-the-battle-for-the-soul-of-lagos-begins. Accessed 14 April 2015.

Robinson, J. (2006a). Inventions and interventions: Transforming cities-An introduction. Urban Studies, 43(2), 251-258.

Robinson, J. (2006b). Ordinary cities: Between modernity and development. London: Routledge.

Rose, N., O'Malley, P., \& Valverde, M. (2006). Governmentality. Annual Review of Law and Social Science, 2, 83-104.

Shatkin, G. (2011). Planning Privatopolis: Representation and contestation in the development of urban integrated megaprojects. In A. Roy \& A. Ong (Eds.), Worlding cities Asian experiments and the art of being global. Oxford: Blackwell.
Sheppard, E. (2014). Globalizing capitalism and southern urbanization. In S. Parnell \& S. Oldfield (Eds.), The Routledge handbook on cities in the global south. London: Routledge.

Simone, A. (2010). The social infrastructure of city life in contemporary Africa. Discussion paper 51, Nordiska Afrikainstitutet. Uppsala: Nordiska Afrikainstitutet.

SNC-LAVALIN. (1995). Community infrastructure upgrading programme-Final report. Lagos: Lagos State Urban Renewal Board.

Swyngedouw, E., Moulaert, F., \& Rodriguez, A. (2002). Neoliberal urbanization in Europe: Large-scale urban development projects and the new urban policy. Antipode, 34(3), 547-582.

The Nation. (2015). Lagos spends N1.132 trillion on infrastructure. http://nigeriamasterweb.com/paperfrmes.hotmail. Accessed 2 May 2015.

TheNews. (2015). Jonathan in Lagos to rig election for PDP, APC alleges. http://thenewsnigeria.com.ng/2015/04/10/ jonathan-in-lagos-to-rig-election-for-pdp. Accessed 14 April 2015.

Ward, K. (2011). Policies in motion and in place: The case of business improvement districts. In E. McCann \& K. Ward (Eds.), Mobile urbanism: Cities and policy making in the global age. Minneapolis: University of Minnesota Press.

Watson, J. (2009). Seeing from the South: Refocusing urban planning on the Globe's central urban issues. Urban Studies, 46(11), 2259-2275.

Watts, W. (2004). Resource curse? Governmentality, oil and power in the Niger Delta, Nigeria. Geopolitics, 9(1), $50-80$. 